DOI: 10.34015/2523-4552.2020.2.02

УДК 340.155.2:343.26

Сокальська О. В., кандидат юридичних наук, доцент

e-mail:co2001@ukr.net

ORCID: 0000-0001-8737-0829

\title{
ЛОКАЛЬНА ТЮРЕМНА РЕФОРМА У ВЕЛИКІЙ БРИТАНІЇ У КІНЦІ ХVIII СТОЛІТТЯ
}

У статті розглянуто та проаналізовано етапи реалізації тюремних перетворень у Британії у кінці XVIII ст. на рівні графств. Визначено нормативні, режимні та управлінські засади діяльності новостворених тюрем та виправних будинків, окреслено їх значення для подальшого розвитку пенітенціарних систем.

Ключові слова: Великобританія; локальна тюремна реформа; виправний будинок; місцева тюрма; одиночне ув'язнення.

В статье рассмотрены и проанализированы этапы реализации тюремных преобразований в Британии в конце XVIII в. на уровне графств. Определены нормативные, режимные и управленческие основы деятельности новых тюрем и исправительных домов, а также их значение для дальнейшего развития пенитенциарных систем.

Ключевые слова: Великобритания; локальная тюремная реформа; исправительный дом; тюрьма графства; одиночное заключение.

Постановка проблеми. Формування пенітенціарних систем у кінці XVIII - на початку XIX ст. стало ілюстрацією процесу глобалізації у сфері кримінальної політики провідних держав світу. Як правило, визнаючи першість у питаннях тюремної реформи Дж. Говарда, дослідники забувають, що відомий філантроп перші свої інспекції тюрем здійснив на Батьківщині, у результаті чого було ухвалено та реалізовано реформаторські нормативно-правові акти щодо покращення устрою виправних будинків та тюрем графств. Однак, Об'єднане Королівство не розглядається як країна, що започаткувала тюремно-пенітенціарний тренд, що набув такої популярності у XIX ст.
У другій половині XIX ст. Артур Гріффітц (Arthur Griffiths) писав, що тема тюремної дисципліни стала проблемою № 1, дискусії навколо неї заполонили шпальти газет, політики ії обговорювали як у стінах парламенту, так і загалом у світі [1, p. 182].

Аналіз останніх досліджень i публікацій. Питання локальної тюремної реформи розглянуто переважно в контексті тюремних перетворень у Великобританії у кінці XVIII ст. Цій проблематиці присвячено загальні праці Ш. Мак-Конвіла (S. McConville), Б. Уебб (B. Webb) i C. Уебб (S. Webb). Цінним джерелом для написання статті стали локальні тюремні акти відповідних графств та Акт про виправні будинки 1782 р., 
огляди тюрем Дж. Говарда (John Howard), Дж. Нілда (James Neild), звіт Томаса Бівера (Thomas Beevor) щодо фундації виправної тюрми в Ваймондхемі у Норфолку.

Постановка завдання. Мета статті - розглянути та проаналізувати етапи реалізації тюремних перетворень у Британії у кінці XVIII ст. на рівні графств, визначити нормативні, режимні та управлінські засади діяльності новостворених тюрем та виправних будинків, окреслити їх вплив на формування пенітенціарних систем.

Виклад основного матеріалу. Праці англійських правників, філософів і філантропів щодо реформування тюрем та Пенітенціарний акт 1779 р. заклали як теоретичне, так i нормативне підгрунтя для масштабної тюремної реформи. Ї̈̈ відправною точкою стало ухвалення Тюремного акта 1774 р. У цей же час проводились системні інспекції місць ув'язнення Дж. Нілдом, В.Смітом i, звичайно, Дж. Говардом. У контексті цього руху ще у середині 70-х років в окремих графствах перебудовано кілька місцевих тюрем [2, p. 164].

Нормативна регламентація заміни транспортації каторжними роботами та виконання цього виду покарання відбувалася паралельно 3 розробкою начал тюремної реформи. Ці два рухи у сфері виконання покарань у Британії у 70-90-х роках XVIII ст. стали визначальними для формування модерної англійської тюремної системи й, у подальшому, пенітенціарних систем країн світу.

У 80-і роки XVIII ст. у країні розпочався справжній тюремний будівельний бум. Загалом було збудовано понад п'ятдесят нових в'язниць i виправних будинків. Якщо у другій половині 60-х років у графствах зведено лише 1 місцева тюрма та 5 виправних будинків, то вже у 70-і роки - 9 тюрем та 5 виправних будинків, а впродовж 80-х - на початку 90-х років - 30! нових закладів (3 місцеві тюрми та 27 виправних будинків) [2, p. 163-164, 167].

Що ж стало причиною таких активних тюремних перетворень? По-перше, неможливість транспортації, а з відновленням перевезення злочинців до Австралії 1786 р., її коштовність. По-друге, спалах 1783 р. тюремної лихоманки [3, p. 12681269]. Окремі автори зазначають, що не так потреби держави чи іï кримінальна політика вплинули на реформу тюрем, як постійні епідемії серед засуджених, які нерідко були загрозою для усього міста. Це і змусило лікарів, філантропів та релігійних діячів опікуватися реформою місць ув'язнення [4, p. 15-16]. Магістрати 3 остраху перед масовими захворюваннями виділяли необхідні кошти для побудови безпечних, з точки зору гігієни, тюрем, відповідно до ідей, що їх пропагували тюремні реформатори. Найбільш популярним серед них був звичайно Дж. Говард. Його книга Стан тюрем Англії та Уельсу крім опису неналежного стану тюрем країни, містила модель зразкової тюрми, організованої на нових принципах та режимі утримання, яка й стала орієнтиром на місцях.

При розробці проєктів тюрем графств архітектори орієнтувалися на приписи Пенітенціарного акта 1779 p. і теоретичні розробки принципів організації місць відбування покарання, їх розташування за межами міста, внутрішньої організації простору, розміщення камер, майстерень, приміщень для наглядачів тощо. Но- 
возведені заклади продовжували традиційно іменувати: місцева тюрма (county gaol), брайдвел (bridewell) або виправний будинок (house of correction), але вони суттєво відрізнялись від відповідних місць утримання, започаткованих ще в середньовіччя. Оскільки були організовані на абсолютно інших засадах, а саме: роздільне утримання різних категорій ув'язнених (жінки і чоловіки, підслідні, засуджені за тяжкі злочини, дрібні злочинці, боржники), перебування в неробочий час в окремих камерах (переважно одиночних), праця засуджених, навчання ремеслам, сувора дисципліна та дотримання норм гігієни, обов'язкова релігійна опіка, система дисциплінарних стягнень і заохочень, вимоги до персоналу, контроль і нагляд з боку суддів.

Однин із перших закладів нового типу відкрито 1779 р. у Хоршемі (Західний Сассекс) 3 ініціативи Чарльза Леннокса, 3-го герцога Річмонда, відомого своїми прогресивними поглядами. Рішення про побудову нової тюрми (county gaol) ухвалено на квартальних сесіях ще 1775 р. [5, р. 124] як продовження починань, закладених Тюремним актом 1774 р. [6, р. 89].

На той час це був єдиний заклад камерного типу у Британії, зведений відповідно до ідей тюремних реформаторів. Будівля в'язниці площею 132 фута на 32 фута віддалена від інших споруд й огороджена по периметру стіною висотою 20 футів. В окремому корпусі - лазарет, каплиця та житлові приміщення тюремників. На території - просторі внутрішні дворики [7, р. 277]. Вартість будівельних робіт склала $3560 £$ [5, p. 124].

На квартальних судових сесіях у серпні 1779 р. розроблено та затверджено Правила та приписи для управ- ління тюрмою. Вони охоплювали 32 статті, у яких детально регламентовано засади організації діяльності тюрми (режим, роздільне утримання, облаштування одиночних камер, повноваження та оплата праці тюремних службовців тощо). Про реформаторський (виправний) вплив на засуджених через працю чи будь-які інші засоби у правилах не йшлося. Увага була зосереджена на режимі утримання, засадах управління в'язницею, повноваженнях персоналу, оплаті праці тощо [6, р. 90].

Начальник тюрми (gaoler) в Хоршемі отримував $100 £$ на рік, а також забезпечувався житлом на території в'язниці. Він повинен був призначати наглядачів (у такій кількості, щоб двоє 3 них щодня несли службу). Тюремним службовцям заборонялося продавати засудженим будь-які товари. Боржники та злочинці були розділені у різних крилах будівлі, камери для жінок розташовувалися у кінці корпусу. Запеклі злочинці утримувалися окремо від дрібних шахраїв, на іншому поверсі [8, p. 35]. Усі засуджені вночі перебували в одиночних камерах розміром 10 футів на 7 футів і висотою 9 футів [9, p. 270-271]. У кожній камері: дерев'яне ліжко, матрац, набитий соломою, та дві ковдри. Також у кожному крилі були загальні кімнати (day rooms), що зимою опалювалися вугіллям [7, р. 278].

Дж. Нілд, відвідавши Хоршем 3 інспекцією у 1806 р., відмітив, що в'язниця достатньо забезпечена релігійною літературою, капелан свої обов'язки виконує щоденно, а у неділю відправляє службу (присутність на якій для засуджених була обов'язкова). Також в'язницю регулярно відвідував лікар [7, р. 278]. 
Новоприбулі засуджені та боржники піддавалися санобробці. Усім ув'язненим видавали тюремний одяг: жилет, бриджі, дві сорочки, дві пари панчіх, туфлі, капелюх та шерстяну шапку [9, p. 271]. Боржникам дозволялося працювати. Але їм не часто вдавалося підшукати замовлення [7, p. 277-278]. Загалом Дж. Нілд відмічав, що на початку XIX ст. основною проблемою у подібних закладах була трудова зайнятість як боржників, так і засуджених, і більше уваги слід приділяти заохоченню їх до праці [7, p. 278].

3 огляду на дату відкриття виправної тюрми у Західному Сассексі 1779 р., очевидно, що нормативне закріплення засад роздільного, одиночного утримання й правил управління тюрмою у Пенітенціарному акті 1779 р. відбувалося паралельно з практичною реалізацією цих принципів у Хоршемі. Це зайвий раз доводить закономірність і поступальність процесу тюремних перетворень у Великобританії у другій половині 70-х років XVIII ст.

У цей же період 1779 р. відкрито карний заклад камерного типу у Бодміні (Bodmin) у графстві Корнуолл. Новаторський проєкт тюрми (county gaol) підготовлено на замовлення місцевого судді Джона Колла (John Call), який 1778 р. отримав на це дозвіл парламенту. Тюремні правила закладу (Articles Regulations and Allowances established for the Gaol Bridewell and Sheriff's Ward at Bodmin) також співпадали з окремим приписами Пенітенціарного акта 1779 p. [10, p. 396-397].

Тюрма в Бодміні, як зазначав Дж. Колл, - знак шани Дж. Говарду. I дійсно, за архітектурним рішенням вона нагадувала план взірцевої в'язниці Дж. Говарда [11, р. 48-49], але $з$ меншим внутрішнім двором та більшою площею камер [8, p. 36]. Комплекс тюремних будівель, зведений на околиці міста, об'єднував тюрму для злочинців (county jail), боргову тюрму (debtor's prison) і виправний будинок (house of correction), мав централізоване водопостачання, обладнання для підігріву води тощо [12]. Окремо розташовувалися лазарет, каплиця та будинок наглядача.

Різні категорії ув'язнених: злочинці, боржники, засуджені до перебування у виправному будинку утримувалися в окремих корпусах. Таке ж розділення було щодо жінокув'язнених. У позаробочий час усі перебували в одиночних камерах розміром 8 на 5,8 футів і висотою 7 футів [8, p. 36]. Для кожної категорії - окремі загальні кімнати площею 47 на 14 футів. Боржники утримувалися в осібному приміщені, по двоє в камері. Але за бажанням і за умови відповідної плати могли перебувати в камері одноосібно. У каплиці під час богослужінь різні категорії ув'язнених теж розміщувалися окремо [7, p. 51-52]. Одночасно у Бодміні могло перебувати до 200 засуджених [13, p. 8].

Тюремні правила забороняли стягувати garnish ${ }^{1}$ або будь-які плати 3 новоприбулих ув'язнених, грати в

\footnotetext{
1 Garnish - традиційна плата, що стягувалася в англійських в'язницях з новоприбулих ув'язнених на користь співкамерників або як «пожертвування» на потреби «тюремного загалу», як правило, ці кошти засуджені витрачали на алкогольні напої. У того, хто не міг заплатити, забирали одяг або били різками.
} 
азартні ігри, вживати алкоголь. Не допускалося жорстоке поводження чи утиски з боку одних засуджених щодо інших (винуватців карали поміщенням у більш суворі умови утримання, тяжкою працею або зменшенням оплати праці). Кайданки могли застосовуватися до засуджених як виняток, лише у разі необхідності задля покарання чи забезпечення безпеки. Суддям та шерифу приписувалося, якомога частіше відвідувати тюрму й вислуховувати скарги засуджених. Начальник тюрми повинен був вести реєстр ув'язнених, де вказувалися прізвище та ім'я кожного, дата поміщення до тюрми, місце проживання, ким і за що був засуджений, зауваження щодо його поведінки під час ув'язнення [10, р. 396-397].

Правила встановлювали чіткий розпорядок дня й приписували, що всі засуджені повинні бути зайняті роботами, які тривали 10 годин на день у теплу пору року й 8 годин взимку. 2/3 від зароблених засудженими коштів надходили до спеціального фонду, за рахунок якого утримувалася в'язниця, 1/6 прибутку виплачувалася засудженому й 1/6 начальнику тюрми [10, р. 396]. Жінки прали, ремонтували одяг засуджених i пряли шерсть. Чоловіки займались розпилом деревини, тесанням каміння для будівництва, працювали на ткацьких станках. Завданням начальника тюрми було забезпечити засуджених матеріалами та замовленнями. Під час чергової інспекції в'язниці 1787 р. Дж. Говард відмітив, що засуджені отримували фіксовану платню [9, р. 394]. Станом на початок 1800-х років усі засуджені були забезпечені роботою. Дж. Нілд зазначав, що завдяки цьому, багато 3 них змогли утримувати сім'ї та навчитися ремеслу. Один із засуджених після звільнення зізнався, що перебування в тюрмі для нього стало найщасливішим періодом у житті, оскільки саме тут він навчився працювати на пилорамі, що дозволило йому заробляти 2 гінеї в тиждень. Магістрат дозволив четверту частина коштів, зароблених засудженими, залишати на в'язничні потреби [7, p. 53].

До проєктів цього періоду, розроблених під впливом ідей Дж. Говарда, слід віднести й жіночу тюрму в Йорку. Конкурс на її будівництво оголошено у березні 1779 р. Вона мала стати складовою комплексу, що зводився під керівництвом Джона Карра (John Carr) і включав також будівлі суду й боргової тюрми. Жіноча тюрма в Йорку побудована упродовж 1780-1783 pp. [14]. Загальна вартість проєкту авторства Томаса Вілкінсона і Джона Прінса (Thomas Wilkinson, John Prince) склала $1540 £$. Судячи з плану, передбачалося, що засуджені будуть розміщатися або осібно, або по двоє в камepi.

У 1782 р. парламентом ухвалено загальнодержавний Акт про внесення змін і доповнень до законів, що регламентують діяльність виправних будинків (An act for the amending and rendering more effectual the laws in being relative to houses of correction) [15], що уніфікував нормативні приписи у цій сфері. Його ініціатором був Томас Гілберт (Thomas Gilbert) [6, p.93]. У тому ж 1782 р. парламент ухвалив розроблений ним Акт про надання допомоги бідним (The Relief of the Poor Act), більш відомий як Акт Гілберта, що передбачав організацію допомоги на 
рівні графств бідним, сиротам та інвалідам і започаткування для цього спеціальних закладів (poorhouse або workhouse) [16].

Акт про виправні будинки 1782 р. вперше на загальнодержавному рівні детально регламентував питання розробки планів виправних тюрем задля роздільного утримання та управління ними. Старший наглядач чи управитель виправного будинку (ст. X забороняла жінкам займати цю посаду) повинен був призначатися на квартальних сесіях місцевих судів. Він організовував тюремні роботи, наймав відповідний персонал, підшукував замовлення, закуповував матеріали, вів облік засуджених та виконаних ними робіт і звітував про це на квартальних сесіях [15, p. 93]. Засудженим приписувалося виплачувати половину прибутку від в'язничної праці, але лише в момент звільнення, а не раніше (ст. VII). Розмір заробітної плати управителя встановлювали судді, але допускалося, що він отримуватиме певний відсоток прибутку від тюремних робіт (ст. IX). Судді наймали та встановлювали платню тюремному священнику (не більше $20 £$ ) і лікарю, а також призначали інспектора для нагляду за місцями ув'язнення, який звітував би на квартальних сесіях про стан тюрем [6, p. 93].

Окремо зазначалося, що за постачання засудженим алкоголю тюремним наглядачам загрожує штраф і звільнення з посади (ст. VIII). Начальник виправної тюрми мав право накладати на засуджених дисциплінарні стягнення, але повинен був упродовж 48 годин повідомити про це суддю, що здійснював нагляд за виправним будинком.
Акт 1782 р. також містив типові правила «внутрішнього розпорядку» виправних будинків. Судді могли вносити додаткові приписи для кожного конкретного виправного будинку, але вони не повинні були суперечити нормам, встановленим цим актом. Правила слід було надрукувати розбірливим шрифтом і вивісити на видному місці у кожному виправному будинку (ст. IV). Наводимо текст цих типових правил:

\section{Правила й настанови, яких мають дотримуватися \\ у кожному виправному будинку}

I. Особи, засуджені до каторжних робіт і поміщені до виправного будинку, повинні залучатися до тюремних робіт, якщо дозволить їх стан здоров'я, кожен день, окрім неділі, Різдва та Страсної П'ятниці, упродовж світового дня, залежно від пори року, але не більше ніж 12 годин на день, $з$ перервою по півгодини на сніданок та вечерю.

II. Управляючий виправним будинком повинен пристосовувати різі види робіт, встановлені суддями на квартальних сесіях, до конкретних потреб, навиків та можливостей засуджених, з огляду на їх вік та стать.

III. Чоловіки та жінки, поміщені до виправного будинку, повинні забезпечуватися роботою, утримуватися та харчуватися окремо, не вступаючи у будь-який контакт.

IV. Усі засуджені мають бути забезпечені хлібом і простою, але корисною їжею та водою; для тих, хто перебуває у лазареті, дієту встановлює лікар.

V. Управитель виправного будинку та інші службовці повинні бути дуже пильними та відповідальними, наглядати за дотриманням 
режиму й в'язничними роботами; у разі порушення встановлених правил, пошкодження матеріалів чи неробства - карати, відповідно до приписів, встановлених цим актом.

VI. Якщо засуджений, вчинить дисциплінарний проступок: відмовиться виконувати наказ управляючого чи наглядача, буде лаятись чи словесно ображати, непристойно себе поводити, то має бути підданий дисциплінарному покаранню.

VII. Управитель (начальник тюрми) наділений повноваженнями карати за дисциплінарні проступки більш суворою ізоляцією; всі такі випадки повинні фіксуватися в спеціальних книгах, які перевіряються суддями, де б вказувалося прізвище засудженого, проступок та вид стягнення [15, р. 96-97].

Як ці приписи реалізувалися на практиці можемо прослідкувати на прикладі виправної тюрми в Ваймондхемі (графство Норфолк). Її було зведено 1784 р. за ініціативи Томаса Бівера замість колишнього брайдвела, який Дж. Говард назвав «найжахливішою тюрмою в усій Англї̈». Вартість будівництва склала $2395 £$ [2, p. 167]. Т. Бівер надихався, як він сам писав, книгою та ідеями Дж. Говарда $[17$, р. 87]. Будівля тюрми П-подібної форми зведена відповідно до приписів парламентського акта 1782 р. 3 роздільним утриманням різних категорій засуджених. Облаштовано окремі просторі, чисті камери (розміром 14 на 8 футів), в яких засуджені не лише перебували в ночі, але й могли, за необхідності, працювати в день. Також у кожному крилі будівлі були загальні кімнати для роботи, на другому поверсі, де утримувались у різних частинах жінки та дрібні злочинці, приміщення під лазарет. При плануванні камер особливу увагу звертали на доступ свіжого повітря до приміщення й запобігання пожежам. Камери мали склепінчасту стелю, вікна, досить великі, на відстані 7 футів від підлоги, загратовані. Скло на вікнах було лише в лазареті та камері, де утримувалися жінки з немовлятами.

У виправному будинку у Ваймондхемі було організоване виробництво: чоловіки займались розпилом деревини, що постачалась у Норвич, і биттям конопель, жінки пряли. Засуджений, старанно працюючи, заробляв від 8 до 10 шилінгів на тиждень. У звіті управляючого у перший рік функціонування виправного будинку зазначалося, що прибуток від в'язничної праці був навіть дещо більшим ніж витрати на утримання засуджених. I хоча, як зауважував Т.Бівер, це не було самоціллю, але він не вбачав нічого поганого в тому, щоб отримувати користь від праці засуджених, які донедавна були втрачені для суспільства, що також доводить недоцільність їх відправки за межі королівства. Більшою мірою це була заслуга управителя виправного будинку (він окрім заробітної плати, отримував 3 пенси від кожного шилінга чистого прибутку), який настільки добре організував його діяльність, що звільнив магістрат від зайвого клопоту [17, р. 91-92].

Фундатори виправного будинку сподівалися, що роздільне утримання, яке стало основою тюремного режиму, поєднане з працею та сумирною поведінкою, буде сприяти змінам у свідомості злочинців, у результаті чого вони стануть доброчесними громадянами. Самотність, як зазначав Т. Бівер, позитивно впливає на самих запеклих злочинців [17, р. 87- 
88, 92]. Такі заклади, завдяки одиночному утриманню, мали б не лише сприяти виправленню злочинців, але запобігати вчиненню злочинів іншими [17, р. 93].

На основі типових правил парламентського акта 1782 р. та окремих положень Пенітенціарного акта 1779 р. Т. Бівер розробив Правила й приписи, встановлені для виправного будинку графства Норфолк (Rules orders and regulations to be observed and enforced at the Houses of Correction in the county of Norfolk). Автор зазначав, що, можливо, комусь ці правила видадуться занадто суворими. Але, на думку Т. Бівера, тюрма має бути місцем дійсно покарання, де немає місця розвагам засуджених чи потуранням наглядачів. Деяке послаблення режиму утримання допускалося щодо дрібних злочинців: їм дозволялося працювати в товаристві. У разі переповненості тюрми, вони могли утримуватись у камерах по двоє. Хворих засуджених оглядав лікар чи аптекар.

Їжа засуджених хоча й була скудною, але, на думку фундатора закладу, корисною. Меню виправного будинку Ваймондхема складало: на сніданок щодня невелика хлібина (анг. penny loaf), на обід: у неділю Суп Хенуея з бичачої щоки (не зовсім зрозуміла назва супу, але з огляду на безліч новаторських пропозицій Дж. Хенуея щодо тюрем та госпіталів, дозволимо собі припустити, що це якийсь прообраз супу-пюре, відомого як суп Румфорда, який Томас Румфорд упровадив дещо пізніше у прусських робітних будинках - O.C.), у понеділок - хлібина, у вівторок - картопля, у середу - варений горох, у четвер - хлібина, у п'ятницю - картопля, у суботу - варений горох.
Дж. Нілд у звіті про стан тюрем 1810 р. подає той самий перелік страв у Ваймондхемі [7, p. 600]. Отже, «тюремне меню» залишалось незмінним упродовж 25 років.

Нагляд та контроль за діяльністю і станом виправного будинку здійснювали місцеві судді. На кожну квартальну сесію подавалися відповідні звіти [17, р.89]. Перші сім статей Правил і приписів, встановлених для виправного будинку в графстві Норфолк були типовими, узятими 3 акта 1782 р. В інших управителю приписувалося не допускати спілкування між засудженими за тяжкі злочини та іншими ув'язненими, зокрема, і працювати вони повинні окремо від інших (ст. VIII, IX), за можливості, під час робіт засуджені мають бути максимально розділені (ст. XII); заборонялося продавати або передавати засудженим речі та алкоголь (ст.Х). Засуджені повинні були щодня прибирати свої камери, щотижня слід було міняти їм солому у матрацах і видавати чисту сорочку (ст. XI, XV). На ніч усіх засуджених замикали у камерах (ст. XII). Окрема стаття визначала, що кожен засуджений зобов'язаний мити лице та руки, хоча б раз у день, перед їжею (ст. XIV).

T. Бівер був переконаний, що превентивне правосуддя набагато доцільніше карального, тому започаткування виправних будинків вважав гуманною і необхідною справою, сподіваючись, що такі заклади буде відкрито у кожному графстві [17, p. 89, 93].

Карні заклади, що відкривалися по всій країні, і дійсно були більше превентивними, а не виправними. На думку Ш. Мак-Конвіла, будь-які сподівання на виправлення злочинців, 
які утримувалися у цих в'язницях, були радше абстрактними й випадковими. Один із біографів Дж. Говарда навіть зазначав, що як би не релігійна складова, то тюремного реформатора можна було б звинуватити у ставленні до засуджених як до тварин, які не задумуються над своїми вчинками й майбутнім - їм лише потрібно чисте сухе житло й достатньо їжі. Ідеальну тюрму Дж. Говарда можна уявити як сучасний зоопарк, де тварини утримуються в чистоті, а контролюють їх достойні наглядачі [6, p. 92]. I хоча це дуже спрощений підхід, але, на нашу думку, він не позбавлений певного сенсу, особливо з точки зору ідеологів концепту виправного впливу на злочинців, що досить скоро утвердився в англійській пенальній практиці.

Першим закладом, в основу режиму якого покладено ідеї реформаторського впливу на засуджених і принципи суворого одиночного утримання, став виправний будинок в Петворті (Західний Сассекс), відкритий 1787 р. Нагадаємо, що у графстві з 1779 р. уже функціонував виправний будинок у Хоршемі за системою одиночного утримання вночі і спільних робіт удень. Правила виправного будинку в Петворті, розроблені на квартальних судових сесіях й утверджені 1788 р., забороняли контакти між засудженими: вони повинні були перебувати у своїх камерах і вдень, і вночі, виконуючи таку роботу, яка можлива в умовах суворого одиночного утримання [8, p. 39].

В основу діяльності та режиму утримання в Петворті було покладено не стільки ідеї Дж. Говарда, який не був прихильником суворого одиночного утримання, хоча і допускав, що «усамітнення та мовчання спри- яють роздумам і можуть призвести до покаяння» [6, p.98], як концепт виправного одиночного ув'язнення, який відстоювали представники протестантських церков, а теоретично розробив й обгрунтував Дж. Хенуей.

Проєкт виправного будинку у Петворті (Petworth House of Correction) було розроблено відповідно до режиму суворого одиночного утримання. На першому та другому поверсі виправного будинку розташовувалося по 16 камер, кожна розміром 13 на 10 футів (які були значно більші за площею ніж в інших закладах). У камері залізне ліжко, матрац, набитий соломою, та дві ковдри. На вході - дерев'яні двері та залізна решітка. На кожному поверсі приміщення під лазарет (це єдині кімнати, які опалювалися). Упродовж 1 години кожного дня засуджені наодинці могли перебувати на свіжому повітрі. У каплиці виправної тюрми вони також були ізольовані один від одного. У ній було 32 окремі лавки, що мали з боків загородки, і засуджені не могли бачити один одного. Але усіх їх було видно капелану. Контроль за діяльністю виправної тюрми здійснював магістрат [7, р. 707]. Одиночна система проіснувала у в'язниці Петворта до 1816 р. [8, p. 39].

Фактично, устроєм цього закладу було реанімовано окремішність виправних закладів від звичайних тюрем, не лише за назвою, але й за змістом: за мету утримання у них визначалося саме виправлення злочинця [6, p. 94].

«Моду» на побудову новаторських карних закладів не всі сприймали з захопленням. Майже відразу такі коштовні проєкти викликали 
невдоволення платників податків. Так, у Петворті декілька сотень місцевих фермерів і торговців звернулись 3 петицією до окружних суддів, що нова тюрма була занадто дорогою і витрати на неї зовсім невиправдані. Вони просили, щоб видатки на будь-яку нову тюрму не перевищували $1000 £$ [18]. Отже, бачимо, що проблема економічної обгрунтованості, паритету інтересів платників податків та суспільної безпеки, супроводжувала модерну тюрму від самого ії виникнення і до нині.

Висновки. Ідеї тюремних реформаторів Дж. Хенуея, В. Ідена, В. Блекстона, Дж. Говарда та приписи Пенітенціарного акта 1779 р. уперше було реалізовано в Об'єднаному Королівстві не на загальнодержавному рівні, а в графствах в якості реформаторської ініціативи місцевих еліт. Магістрати здійснювали будівництво відповідно до локальних тюремних актів для кожного графства, ухвалених парламентом. Устрій та режим перших виправних закладів розроблено на основі приписів Пенітенціарного акта 1779 р. та рекомендацій, що містилися у книзі Дж. Говарда Стан тюрем Англії та Уельса. Для кожного виправного будинку було розроблено правила утримання, а 1782 р. парламентом ухвалено Акт про виправні будинки, що містив типові правила.

Новозведені заклади були організовані на абсолютно інших, порівняно з дореформеними тюрмами та виправними будинками, засадах, а саме: роздільне утримання різних категорій ув'язнених (жінки і чоловіки, підслідні, засуджені за тяжкі злочини, дрібні злочинці, боржники), перебування в неробочий час в окремих камерах (переважно одиночних), праця засуджених, навчання ремеслам, сувора дисципліна та дотримання норм гігієни, обов'язкова релігійна опіка, система дисциплінарних стягнень і заохочень, вимоги до персоналу, контроль і нагляд з боку суддів.

Але ці заклади були переважно превентивними, а не виправними. Вперше режим утримання, заснований на ідеях реформаторського впливу й принципах суворого одиночного утримання, було впроваджено у виправному будинку в Петворті. Фактично, устроєм цього закладу було реанімовано окремішність виправних будинків від звичайних тюрем, не лише за назвою, але й за змістом.

На прикладі формування засад режиму утримання у виправних будинках у Хоршемі (спільне утримання вдень та розділення на ніч) та Петворті (суворе одиночне ув'язнення) можемо прослідкувати зародження двох систем тюремної дисципліни, що у наступному столітті конкуруватимуть за першість у пенальних практиках більшості країн світу. Вони з історичною симетрією ілюструють як зародилася системи превентивного та виправного утримання в межах каральної політики.

\section{References}

1. Griffiths, A. (1875). Memorials of Millbank, and Chapters in Prison History. H. S. King.

2. Chalklin, C. W. (1998). English Counties and Public Building, 1650-1830. London. 
3. Fisher, G. (1995). The Birth of the Prison Retold. Yale Law Journal. Volume 104, Issue 6, 1235-1324.

4. Porter, Roy. (1995). 'Howard's beginning: prisons, disease, hygiene. Richard Creese, William F Bynum, J Bearn (eds). The health of prisoners: historical essays. Rodopi, Amsterdam \& Atlanta, 5-26.

5. Third report of inspections of Great Britain. To visit the different prisons of Great Britain. (1838). Parliament. House of Lords.

6. McConville, S. (1981). A History of English Prison Administration: 1750-1877. London : Routledge \& Kegan Paul.

7. Neild, James (1812). State of the prisons in England, Scotland and Wales.

8. Brodie, Allan, Croom, Jane and James, O. Davies (2002). English Prisons: An Architectural History. English Heritage.

9. Howard, J. (1792). The state of the prisons in England and Wales with preliminary observations, and an account of some foreign prisons and hospitals (4 ed.). London: Johnson, Dilly and Cadell.

10. Howard, J. (1784). The state of the prisons in England and Wales: With Preliminary Observations, and an Account of Some Foreign Prisons and Hospitals, Vol. 1. (3 ed.). London: Cadell.

11. Howard, J. (1777). The state of the prisons in England and Wales: with preliminary observations, and an account of some foreign prisons. Warrington: Printed by William Eyres.

12. A Brief history of Bodmin Jail. URL: http://www.bodminjail.org/about-thejail/a-brief-history/ (accessed: 25.04.2020).

13. An Account of All the Goals, Houses of Correction, and Penetentiaries in the United Kingdom. 1819.

14. Rchme (1972). "The defences of the City of York: an inventory". An Inventory of the Historical Monuments in City of York, Volume 2, the Defences, 57-86.

15. The Statutes at Large: From the Magna Charta, to the End of the Eleventh Parliament of Great Britain, Anno 1761 [continued to 1806]. (1782). By Danby Pickering. By Great Britain; Pickering, Danby. Vol. 34, 91-97. London.

16. Poor Relief Act 1782. URL : http://www.workhouses.org.uk/poorlaws/ 1782act.shtml (accessed: 20.03.2020).

17. The Annual Register, Or, A View of the History, Politics, and Literature for the Year 1786. (1788). V. 28. London, Printed for J. Dodsley in Pall Mall.

18. Davie, N. When was the prison? Thinking and re-thinking the penitentiary in Britain, 1770-1850 (unpublished seminar paper, 2013).

O. Sokalska, PhD in Law, Associate Professor e-mail: co2001@ukr.net; ORCID: 0000-0001-8737-0829

\section{Local prison reform in Great Britain in the late 18th century}

In the article the author considered and analyzed the reasons and stages of local prison reform in Great Britain at the end of 18th century. The author defined the regulatory, regime and management framework for prisons and county correctional houses. English lawyers, philosophers, philanthropists laid the theoretical foundations for a large-scale prison reform. The Penitentiary Act 1779 became the normative basis. The starting point of the reform was the adoption of the Prison Act 1774. The formation of penitentiary houses for people sentenced to 
transportation and the reform of local prisons and correctional houses were key movements in the British penal system in the 70-90s. This was what influenced the development of Britain's prison system and, later on, the penitentiary systems of countries around the world.

In 80-90s of the 18th century in England began a real prison building boom: more than fifty new prisons and correctional houses were built. The newly built institutions continued to be traditionally called county gaol, bridewell or house of correction, but they differed significantly from the corresponding places of detention, which appeared in the Middle Ages. Since they were organized according to completely different principles: separation of different categories of prisoners (women and men, those under investigation, those convicted of serious crimes, petty criminals, debtors), stay outside working hours in separate cells (mostly single), work of convicts, training in crafts, strict discipline and hygiene, necessarily religious guardianship, system of disciplinary sanctions and benefits, staff requirements, control and supervision by judges.

Keywords: Great Britain; local prison reform; bridewell; county gaol; solitary confinement. 